\title{
Effect of Corrosion on the Flexural Strength of Reinforced Concrete Structures with Corroded and Coated Members
}

\author{
Charles Kennedy ${ }^{1}$, Toscanini Dein Seimodei ${ }^{2}$, Geofrey Banje ${ }^{3}$ \\ Faculty of Engineering, Department of Civil Engineering, Rivers State University, Nkpolu, \\ Port Harcourt, Nigeria. \\ ${ }^{2,3}$ Faculty of Engineering, Department of Civil Engineering, Niger Delta University, \\ Wilberforce Island, Bayelsa State \\ Authors E-mail: ${ }^{1}$ ken_charl@yahoo.co.uk, ${ }^{2}$ \\ toscanini1468@yahoo.com, ${ }^{3}$ banjoffy@yahoo.com,
}

ABSTRACT
Corrosion of reinforcing steel embedded in concrete results to degradation and loss of structural strength of reinforcing steel which in turns has led to untimely collapse of many structures exposed to marine coastal environments with severe weather. This work examined the flexural strength characteristic of concrete beam of non-corroded, non-coated and celtis zenkeri exudates / resins coated specimens with varying coated thicknesses. Reinforcing steels were embedded in concrete beams, immersed in harsh marine environment and accelerated for 150 days in pond tank with mixture of $5 \% \mathrm{NaCl}$ solution to water percentages. The results of flexural failure load values of corroded samples average percentile value of $32.0242 \%$ against $47.11112 \%$ and $46.7759 \%$ of non-corroded and celtis zenkeri exudates/ resins coated specimens. Midspan deflection average values with percentile value of $77.89474 \%$ against $-43.787 \%$ and $-44.8743 \%$ non-corroded and coated specimens. Average yield strength, has $100 \%$ with $0.00 \%$ of percentile value. Average ultimate tensile strength with percentile value of $-10.2433 \%$ against $11.41226 \%$ and $11.70662 \%$ of non-corroded and coated specimens. Average strain percentile value of $-10.9478 \%$ against $12.29364 \%$ and $12.82435 \%$ of non-corroded and coated specimens. Average elongations percentile value of $41.8705 \%$ against $72.02975 \%$ and $70.21979 \%$ for non-corroded and coated specimens. Comparative results of non- coated (corroded) to non-coated and coated members showed that corroded members have high flexural failure load with low applied load and high yields, low load with high midspan deflection. Experimental work showed that mechanical properties of reinforcing steel were adversely affected by corrosion with changed in surface properties of non-coated members, while coated members formed resistance surface to corrosion penetration and maintained standard structural properties of reinforcing steel

KEY WORDS: Corrosion, Corrosion inhibitors, Flexural Strength, Concrete and Steel Reinforcement

\section{INTRODUCTION}

The loss and degradation of steel reinforcement strength embedded in reinforced concrete structures are mainly caused by the presence of corrosion. Corrosion of reinforcing steel immersed or embedded in concrete led to the untimely collapse of many structures exposed to marine coastal environments with severe weather. The effect of corrosion on flexural strength has been investigated by a large number of researchers and is well understood. Several studies conducted in this area are explained with a critical evaluation of their applicability to corrosion influences on the flexural strength of reinforced concrete beams. 
Ting \& Nowak (1991) formulated the effect of reinforcing steel area loss calculations arise from mechanical damages resulting from reinforcing steel loss due to corrosion on the load carrying capacity of beams of corrosion presence.

Torres-Acosta et al. (2007) investigated the flexural capacity loss with steel cross-sectional loss due generalized corrosion of embedded steel using specimens of concrete beams with $100 \mathrm{~mm} \times 150 \mathrm{~mm}$ cross section and $1500 \mathrm{~mm}$ in length cast with chlorides. The specimens were tested in flexure under three point loading. They concluded that flexural load capacity decreased by $60 \%$ with only $10 \%$ ratio, the most important parameter affecting flexural load capacity reduction, because pitting corrosion greatly decrease the cross sectional area of the steel at a certain location and change the steel from ductile behavior to brittle behavior.

El-Maaddawy et al. (2005) investigated the flexural action of combined effect of corrosion and sustained loads of reinforced concrete corroded beams. Test results showed that the presence of a sustained load and associated flexural cracks during corrosion exposure significantly reduced the time to corrosion cracking and slightly increased the corrosion crack width. They found that crack width would propagate $22 \%$ faster in loaded conditions, observed that with $8.9 \%$ and $22.2 \%$ mass loss, strength losses of $6.4 \%$ and $20.0 \%$ respectively.

Charles et al. (2018) investigated the residual yield strength structural capacity effect of noncorroded, corroded and inhibited steel bar. The results of coated steel bar with three different resins / exudates extracts of Symphonia globulifera linn, ficus glumosa and acardium occidentale 1.) versus corroded on comparison, the flexural strength failure load are $29.50 \%$, 28.505,29.57\% against $22.30 \%$ corroded, midspan Deflection are 31.14\%,25.30\%, 22.30\% against $39,30 \%$ corroded, tensile strength $11.84 \%, 12.13 \%, 12.14 \%$ against $10.17 \%$ and elongation are $32.40 \%, 32.13 \%, 32.40 \%$ against $46.30 \%$ corroded.

Charles et.al (2018) investigated the effect on flexural residual yield strength capacity of three different resins/exudates extract of trees of dacryodes edulis, moringa oleifera lam, mangifera indica paste coated reinforcement on the concrete beam. Results of flexural strength failure loads of coated members with dacryodes edulis, moringa oleifera lam, mangifera indica are $35.78 \%, 27.09 \%, 29.42 \%$ against $22.30 \%$ decreased in corroded, midspan deflection are $18.57 \%, 28.30 \%, 27.43 \%$ against $39.30 \%$ increased in corroded, elongation are $28.75 \%, 31.50 \%, 31.60$ against $46.30 \%$ increased in corroded and tensile strength are $14.18 \%, 12.29 \%, 12.08 \%$ as against $10.17 \%$ decreased in corroded respectively. Charles et al. (2018) examined the effect/impact of corrosion inhibitors on flexural strength of failure load, midspan deflection, tensile strength and elongation of steel reinforcement layered with resins/exudates of magnifera indica extracts as corrosion inhibitors. More results recorded on experimental work showed flexural strength failure load, midspan deflection, tensile strength and elongation as $29.09 \%, 31.20 \%, 11.75 \%$ and $31.50 \%$ for non-corroded, $29.42 \%, 27.43 \%, 12.09 \%$ and $31.60 \%$ for coated concrete beam respectively.

Rodriguez et al. (1997) studied the level of different corrosion degrees on concrete beams. The studies beam specimens were $200 \mathrm{~mm}$ by $150 \mathrm{~mm}$ with a clear span of $2000 \mathrm{~mm}$. Beams had both tensile, compressive as well as shear reinforcement that was corroded using accelerated corrosion techniques by immersing the specimens in a solution made of $3 \%$ calcium chlorides by weight to the mixing water, over a period of 101-190 days under a constant current density of $100 \mu \mathrm{A} / \mathrm{cm}^{2}$. The results showed that corrosion increases Deflection s and crack widths at the service load, decreases strength at the ultimate load, and causes an increase in both the spacing and width of transverse cracking due to bond deterioration.

Huang \& Yang (1997) investigated the corresponding relationship between the corrosion of reinforced concrete beams and load-carrying capacity. Two beam types of $(150 \times 150 \times 500$ $\mathrm{mm}$, reinforced with two $6 \mathrm{~mm}$ bottom bars) were used: beams without cracks (type S) and 
beams with a middle surface crack (type K). Their results showed significant reduction in load-carrying capacity with the increase in corrosion was more in beams with a low w/c or predetermined cracks (mix B or type K). They concluded that this behavior was a result of the chloride ions having easier access to the reinforcing steel in cracked beams than in uncracked ones.

Charles et al. (2018) investigative study was carried out to ascertained the utilization of natural inorganic extracts of tree resin/exudates to assess the yield strength capacity of reinforced concrete beam members under corrosion accelerated medium. Non corroded and coated members in comparison with corroded recorded increasing values on flexural strength failure load by $23.8 \%$ and $29.59 \%$ against $22.30 \%$ of corroded, tensile strength non corroded and coated increased by $12.03 \%, 12.14 \%$ over $10.17 \%$ of corroded while decreasing values on midspan deflection of $28.30 \%$ and $22.30 \%$, elongation $31.5 \%$ and $32.46 \%$ recorded on non-corroded and coated concrete beam members as against $39.30 \%$ and $46.30 \%$ of corroded respectively.

Charles et al. (2018) investigated the effects of corrosion on the residual structural steel bar capacity of resins/exudates inhibited and non-inhibited reinforced concrete beam members. Results obtained showed corrosion potential presence on uncoated members with cracks and spalling. Further recorded results on non-corroded flexural strength test of failure load $29.09 \%$, midspan Deflection $28.30 \%$, tensile strength $12.03 \%$ and elongation $31.50 \%$, for coated beam members, failure load $29.42 \%$, midspan Deflection $27.42 \%$, tensile strength $12.09 \%$ and elongation $31.80 \%$, for corroded beam members, failure load decreased by $22.50 \%$, midspan deflection increased by $39.30 \%$, tensile strength decreased to $10.17 \%$ and elongation by increased $46.30 \%$.hibitors served as protective coating against corrosion, but no strength was added to steel members.

Otunyo \& Charles carried out to investigate the effect of corrosion on the flexural strength and mid-span deflection of steel reinforcements coated with resins / exudates of trees extract known as inorganic inhibitors. For the corroded steel reinforcement members, result of flexural strength test of failure loads was lower than the dacryodes edulis coated and noncorroded steel reinforcement members, while mid-span deflection was higher for the corroded steel reinforcement members compared to the non- corroded and dacryodes edulis coated stel reinforcement members. Results obtained indicated that the flexural failure strength and elongation increased by and respectively for the dacryodes edulis coated steel members, the mid-span deflection decreased by $26 \%$.

Charles et al. (2018) experimented on the effects of corrosion and inhibitors (Inorganic origin) extracts known as resins/exudates from trees barks on the residual flexural strength of concrete beam members immersed in corrosion accelerated medium for 90 days to ascertain possible changes on surface conditions of investigated samples. Results from this experimental test recorded corrosion potential with visible signs of cracks, color change and spalling. Further results obtained of corroded concrete beam members were 22,50\%, 39.30\%, $10.19 \%$ and 46.30 of failure load, midspan deflection, ultimate tensile strength and elongation, for non- $29.09 \%, 28.30 \%, 12.03 \%$ and $31.50 \%$, for coated beam members , $28.5 \%, 25.30 \%, 12.13 \%$ and $32.12 \%$ respectively.

Charles et al. (2018) performed and investigated on uncoated and corrosion inhibitors (Symphonia globulifera linn) resins / exudates paste coated steel reforcing bar. This was to determine the coating effects of corrosion on flexural load and midspan deflection on structural capacity of reinforced concrete beam members under harsh saline marine environment, represented in the laboratory with sodium chloride $(\mathrm{NaCl})$ as corrosion accelerator. Results obtained confirmed corrosion potential with the presence of stress within the steel and concrete surrounding, spalling and cracking. Further results obtained on comparison between uncoated (corroded) and coated are flexural failure load $22.50 \%$ to 
$29.50 \%$, midspan deflection $39.30 \%$ to $31.14 \%$, tensile strength $10.17 \%$ to $11.84 \%$ and elongation $46.30 \%$ to $32.40 \%$ respectively.

\section{MATERIALS AND METHODS}

\section{Aggregates}

The fine aggregate and coarse aggregate were purchased. Both met the requirements of BS 882

\section{Cement}

Portland limestone cement grade 42.5 is the most and commonly type of cement in Nigerian Market. It was used for all concrete mixes in this investigation. The cement met the requirements of BS EN 196-6

Water

The water samples were clean and free from impurities. The fresh water used was gotten from the tap at the Civil Engineering Department Laboratory, Kenule Beeson Polytechnic, Bori, and Rivers State. The water met the requirements of BS 3148

\section{Structural Steel Reinforcement}

The reinforcements are gotten directly from the market in Port Harcourt. BS 4449:2005+A3

\section{Corrosion Inhibitors (Resins / Exudates) Celtis zenkeri}

The study inhibitor (Celtis zenkeri Exudates) of natural tree resins/exudates extracts.

\section{Methods}

Present study involves direct application of resins / exudates of trees extract known as inorganic inhibitor celtis zenkeri exudates, layered/coated on reinforcement steel ribbed surface. The objective of this study was to determine the usefulness of locally available surface-applied corrosion inhibitors under severe corrosive environments and with chloride contamination. The test setup simulates a harsh marine environment of saline concentration. The samples of reinforced concrete beams of $150 \mathrm{~mm} \times 150 \mathrm{~mm} \times 650 \mathrm{~mm}$, thickness, width and length specimens and ribbed bars of $16 \mathrm{~mm}$ embedded for corrosion test and flexural test for beam was investigated. This was aimed at achieving the real harsh and corrosive state, concrete specimens were ponded in solutions $(\mathrm{NaCl})$ and the depth of the solution was maintained for the given period of experiment as to observe the significant changes that resulted from the actions of the accelerator $(\mathrm{NaCl})$ and the specimens. The determination of the contribution of the resins will be observed through its adhesive ability with the reinforcement through surface coating application and the bonding relationship between the coated specimens and concrete, its waterproofing and resistive nature (resistance) against accelerator penetration into the bare reinforcement.

\section{Specimen Preparation and Casting of Concrete Beams}

Standard method of concrete mix ratio was adopted, batching by weighing materials manually. Concrete mix ratio of 1:2:4 by weight of concrete, water-cement ratio of 0.65 . Manual mixing was used on a clean concrete banker, and mixture was monitored and water added gradually to obtain perfect mix design concrete. Standard uniform color and consistency concrete was obtained by additions of cement, water and aggregates. The test beams were cast in steel mould of $150 \mathrm{~mm}$ x $150 \mathrm{~mm}$ x $750 \mathrm{~mm}$. Fresh concrete mix for each batch was fully compacted by tamping rods, to remove trapped air, which can reduce the strength of the concrete and $16 \mathrm{~mm}$ reinforcements of coated and non-coated were spaced at $150 \mathrm{~mm}$ with concrete cover of $25 \mathrm{~mm}$ had been embedded inside the beam and projection of $100 \mathrm{~mm}$ for half-cell potential measurement. Specimens were molds are removed from specimen after $24 \mathrm{hrs}$ and cured for 28 days. The specimens were cured at room temperature in the curing tanks for accelerated corrosion test process and testing procedure allowed for 
120 days first crack noticed and a further 30 days making a total of 150 days for further observations on corrosion acceleration process.

\section{Flexure testing of Beam Specimens}

Universal Testing Machine in accordance with BS EN 12390-2 was used for the flexural test and a total of 27 beam specimens was tested. After curing for 28 days, 9 controlled beam (non-corroded) was kept in a control state, preventing corrosion reinforcement of the, while 18 beam samples of non-coated and resins / exudates coated were partially place in ponding tank for 120 days placed to examine accelerated corrosion process. After 120 days, the accelerated corrosion subjected samples were examined to determine residual flexural strength. Beam specimens were simply supported on a span of $650 \mathrm{~mm}$. An Instron Universal Testing Machine of $100 \mathrm{KN}$ capacity at a slow loading rate of $1 \mathrm{~mm} / \mathrm{min}$ was used in the flexural test. Beam samples were placed in the machine to specification, flexural test were conducted on a third point at two supports. Load was applied to failure with cracks noticed and corresponding values recorded digitally in a computerized system.

\section{Tensile Strength of Reinforcing Bars}

To ascertain the yield and tensile strength of tension bars, bar specimens of $16 \mathrm{~mm}$ diameter of non-corroded, corroded and coated were tested in tension in a Universal Testing Machine (UTM) and were subjected to direct tension until failure; the yield, maximum and failure loads being recorded. To ensure consistency, the remaining cut pieces from the standard length of corroded and non-corroded steel bars were subsequently used in flexural test.

\section{Flexure testing of Beam Specimens}

Universal Testing Machine in accordance with BS EN 12390-2 was used for the flexural test and a total of 27 beam specimens were tested. After curing for 28 days, 6 controlled beams (non-corroded) was kept in a control state, preventing corrosion of reinforcement, while 18 beam samples of non-coated and exudates /resins coated were partially place in ponding tank for 150 days and examined accelerated corrosion process. After 150 days, the accelerated corrosion subjected samples were examined to determine residual flexural strength. Beam specimens were simply supported on a span of $650 \mathrm{~mm}$. An Instron Universal Testing Machine of $100 \mathrm{KN}$ capacity at a slow loading rate of $1 \mathrm{~mm} / \mathrm{min}$ was used in the flexural test. Beam samples were placed in the machine to specification, flexural test were conducted on a third point at two supports. Load was applied to failure with cracks noticed and corresponding values recorded digitally in a computerized system.

\section{Tensile Strength of Reinforcing Bars}

To ascertain the yield and tensile strength of tension bars, bar specimens of $16 \mathrm{~mm}$ diameter of non-corroded, corroded and coated were tested in tension in a Universal Testing Machine and subjected to direct tension until failure; the yield, maximum and failure loads being recorded. To ensure consistency, the remaining cut pieces from the standard length of corroded and non-corroded steel bars were subsequently used in the bond and flexural test.

\section{RESULTS AND DISCUSSIONS}

Results of 27 samples in table 1,2 and 3 are derived into average values in 3.4 and summarized into summary of averages, percentile values and percentile values difference in 5of flexural strength of concrete beam members as sampled, arbitrarily cast, cured for 28 days on normal and standard method, accelerated in corrosion medium environment for 120days at first crack s observation and 30days extended period and graphically represented in figures $1-4$. 
Non-corroded Concrete Beam Members

The results of flexural failure loads obtained at average of non-corroded members are $82.570 \mathrm{kN}, 82.45667 \mathrm{kN}, 82.926677 \mathrm{kN}$, computed into $82.65111 \mathrm{kN}$ with percentile value of $47.11112 \%$ over $-32.0242 \%$ corroded specimens. Midspan deflection average values are $6.773333 \mathrm{~mm}, 7.016667 \mathrm{~mm}, 6.476667 \mathrm{~mm}$, computed into $6.755556 \mathrm{~mm}$ with and percentile value of $-43.787 \%$ over $77.89474 \%$ corroded specimens. Average yield strength, $460 \mathrm{MPa}$, computed into $100 \%$ with $0.00 \%$ of percentile value. Average ultimate tensile strength, are $628.9833 \mathrm{MPa}, 628.7167 \mathrm{MPa}$, and $628.4167 \mathrm{MPa}$, computed into $628.7056 \mathrm{MPa}$, with percentile value of $11.41226 \%$ over $-10.2433 \%$ corroded specimens. Average strain ratios are $1.317667,1.321$, and 1.311, computed into 1.316556 with percentile values of $12.29364 \%$ over $-10.9478 \%$. Elongations average values are $27.245 \%, 26.96833 \%, 27.36833 \%$, computed into $27.19389 \%$ with percentile value of $72.02975 \%$ over $-41.8705 \%$. Results of non-corroded members at flexural failure load, midspan deflection, yield strength, elongation and strain ratio, all maintained standard and state because they are cure within non-corrosive media.

\section{Corroded Concrete Beam members}

The results of flexural failure load values of corroded samples average are $56.858333 \mathrm{kN}$, $55.805 \mathrm{kN}, 55.885 \mathrm{kN}$, computed into $56.18278 \mathrm{kN}$ with percentile value of $-32.0242 \%$ against $47.11112 \%$ and $46.7759 \%$ of non-corroded and celtis zenkeri exudates / resins coated specimens. Midspan deflection average values are $12.233333 \mathrm{~mm}, 11.933333 \mathrm{~mm}$, $11.88667 \mathrm{~mm}$, computed into $12.01778 \mathrm{~mm}$ with percentile values of $77.89474 \%$ against $43.787 \%$ and $-44.8743 \%$ non-corroded and coated specimens. Average yield strength, $460 \mathrm{MPa}$, computed into $100 \%$ with $0.00 \%$ of percentile value. Average ultimate tensile strength, fu, 565.28333MPa, 563.75MPa, 563.8833MPa, computed into 564.3056MPa, with percentile value of $-10.2433 \%$ against $11.41226 \%$ and $11.70662 \%$ of non-corroded and coated specimens. Average strain ratios are 1.1735333, 1.1802, and 1.163533, computed into 1.172422 with percentile values of $-10.9478 \%$ against $12.29364 \%$ and $12.82435 \%$ of noncorroded and coated specimens. Average elongations are 15.894333\%, $15.674333 \%$, $15.85433 \%$, computed into $15.80767 \%$ with percentile value of $-41.8705 \%$ against $72.02975 \%$ and $70.21979 \%$ for non-corroded and coated specimens. Comparative results of non- coated (corroded) to non-coated and coated members showed that corroded members have high flexural failure load with low applied load and high yields, low load with high midspan deflection. Experimental work showed that mechanical properties of reinforcing steel were adversely affected by corrosion with changed in surface properties of non-coated members, while coated members formed resistance surface to corrosion penetration and maintained standard structural properties of reinforcing steel.

\section{Celtis zenkeri Resins/Exudates Steel Coated Concrete Beam Members}

The results of flexural failure load values of coated samples are $82.401667 \mathrm{kN}, 82.508333 \mathrm{kN}$, $82.47833 \mathrm{kN}$, computed into $82.46278 \mathrm{kN}$ with percentile value of $46.7759 \%$ over $-32.0242 \%$ corroded specimen. Midspan deflection average values are $6.5926667 \mathrm{~mm}, 6.6493333 \mathrm{~mm}$, $6.632667 \mathrm{~mm}$, computed into $6.624889 \mathrm{~mm}$ with percentile value of $-44.8743 \%$ over $77.89474 \%$ corroded specimen. Average yield strength, $460 \mathrm{MPa}$, computed into $100 \%$ with $0.00 \%$ of percentile value. Average ultimate tensile strength, fu, $630.3667 \mathrm{MPa}, 630.4 \mathrm{MPa}$, $630.3333 \mathrm{MPa}$, computed into $630.3667 \mathrm{MPa}$, percentile value of $11.70662 \%$ over $-10.2433 \%$ corroded specimens. Average strain ratios are 1.331667, 1.315, and 1.321667, computed into 1.322778 with percentile values of $12.82435 \%$ over $-10.9478 \%$ of corroded specimen. Average elongation values are $26.89 \%, 26.94667 \%, 26.88667 \%$, computed into $26.90778 \%$ with percentile value of $70.21979 \%$ over $-41.8705 \%$ of corroded specimen. Collated coated 
DOI : https://dx.doi.org/10.26808/rs.aj.i8v1.06

American Journal of Sustainable Cities and Society

Issue 8, Vol. 1 January- December 2019

Available online on http://www.rspublication.com/ajscs/ajsas.html

ISSN $2319-7277$

members result of exudates / resins showed lowers characteristic properties of flexural failure load, midspan deflection, strain ratio and ultimate tensile strength over non-coated (corroded) members in comparison.

Table 1: Flexural Strength of Beam Specimens (Non-Corroded specimens)

\begin{tabular}{|c|c|c|c|c|c|c|c|c|c|c|}
\hline $\mathrm{s} / \mathrm{no}$ & \multicolumn{10}{|c|}{ Non-corroded Control Beam } \\
\hline Beam & Samples & BAK & BBK & CCK & BDK & BEK & BFK & BGK & BHK & BIK \\
\hline ZBK1-1 & $\begin{array}{c}\text { Failure } \\
\text { Load } \\
(\mathrm{KN}) \\
\end{array}$ & 82.63 & 82.63 & 82.45 & 82.42 & 82.42 & 82.53 & 83.23 & 82.2 & 83.35 \\
\hline ZKB1-2 & $\begin{array}{l}\text { Midspan } \\
\text { Deflection } \\
(\mathrm{mm})\end{array}$ & 6.52 & 6.6 & 7.2 & 7.31 & 6.4 & 7.34 & 6.43 & 6.6 & 6.4 \\
\hline ZKB1-3 & $\begin{array}{c}\text { Bar } \\
\text { diameter } \\
(\mathrm{mm})\end{array}$ & 16 & 16 & 16 & 16 & 16 & 16 & 16 & 16 & 16 \\
\hline ZKB1-4 & $\begin{array}{c}\text { Yield } \\
\text { Strength, } \\
\text { fy (MPa) }\end{array}$ & 460 & 460 & 460 & 460 & 460 & 460 & 460 & 460 & 460 \\
\hline ZKB1-5 & $\begin{array}{l}\text { Ultimate } \\
\text { Tensile } \\
\text { Strength, } \\
\text { fu (MPa) }\end{array}$ & 628.15 & 630.05 & 628.75 & 627.55 & 630.05 & 628.55 & 628.35 & 629.15 & 627.75 \\
\hline ZKB1-6 & $\begin{array}{l}\text { Strain } \\
\text { Ratio }\end{array}$ & 1.341 & 1.301 & 1.311 & 1.341 & 1.311 & 1.311 & 1.311 & 1.301 & 1.321 \\
\hline ZKB1-7 & $\begin{array}{c}\text { Elongation } \\
(\%)\end{array}$ & 27.145 & 27.345 & 27.245 & 27.315 & 26.745 & 26.845 & 27.345 & 27.315 & 27.445 \\
\hline
\end{tabular}

Table 2 : Flexural Strength of Beam Specimen (Corroded specimens)

\begin{tabular}{|c|c|c|c|c|c|c|c|c|c|c|}
\hline s/no & \multicolumn{10}{|c|}{ Corroded Beam } \\
\hline Beam & Samples & BAK1 & BBK1 & CCK1 & BDK1 & BEK1 & BFK1 & BGK1 & BHK1 & BIK1 \\
\hline ZKB2-1 & $\begin{array}{c}\text { Failure } \\
\text { load }(\mathrm{KN})\end{array}$ & 57.215 & 57.895 & 55.465 & 54.945 & 57.235 & 55.235 & 55.005 & 57.435 & 55.215 \\
\hline ZKB2-2 & $\begin{array}{l}\text { Midspan } \\
\text { Deflection } \\
(\mathrm{mm})\end{array}$ & 12.47 & 12.3 & 11.93 & 11.9 & 11.5 & 12.4 & 11.93 & 11.53 & 12.2 \\
\hline ZKB2-3 & $\begin{array}{c}\text { Bar } \\
\text { diameter } \\
(\mathrm{mm})\end{array}$ & 16 & 16 & 16 & 16 & 16 & 16 & 16 & 16 & 16 \\
\hline ZKB2-4 & $\begin{array}{c}\text { Yield } \\
\text { Strength, } \\
\text { fy (MPa) }\end{array}$ & 460 & 460 & 460 & 460 & 460 & 460 & 460 & 460 & 460 \\
\hline ZKB2-5 & $\begin{array}{l}\text { Ultimate } \\
\text { Tensile } \\
\text { Strength, } \\
\text { fu (MPa) }\end{array}$ & 567.35 & 563.95 & 564.55 & 563.85 & 563.55 & 563.85 & 563.25 & 564.55 & 563.85 \\
\hline ZKB2-6 & $\begin{array}{l}\text { Strain } \\
\text { Ratio }\end{array}$ & 1.1802 & 1.1702 & 1.1702 & 1.2102 & 1.1602 & 1.1702 & 1.1702 & 1.1602 & 1.1602 \\
\hline ZKB2-7 & $\begin{array}{l}\text { Elongation } \\
(\%)\end{array}$ & 15.911 & 16.051 & 15.721 & 15.251 & 16.241 & 15.531 & 16.051 & 15.751 & 15.761 \\
\hline
\end{tabular}


Table 3: Flexural Strength of Beam Specimens (Exudates/Resins Coated specimens)

\begin{tabular}{|c|c|c|c|c|c|c|c|c|c|c|}
\hline & & \multicolumn{9}{|c|}{ Celtis zenkeri exudates ( steel bar coated specimen) } \\
\hline s/no & & \multicolumn{3}{|c|}{$\begin{array}{l}\text { 150 } \mu \mathrm{m}(\text { Exudate/Resin) } \\
\text { coated }\end{array}$} & \multicolumn{3}{|c|}{$\begin{array}{c}300 \mu m \text { (Exudate/Resin) } \\
\text { coated }\end{array}$} & \multicolumn{3}{|c|}{ 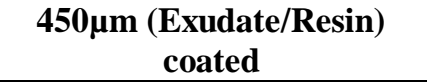 } \\
\hline Beam & Samples & BAK2 & BBK2 & CCK2 & BDK12 & BEK2 & BFK2 & BGK2 & BHK2 & BIK2 \\
\hline ZKB3-1 & $\begin{array}{c}\text { Failure } \\
\text { load }(\mathrm{KN})\end{array}$ & 81.985 & 82.935 & 82.285 & 82.325 & 82.685 & 82.515 & 82.285 & 82.325 & 82.825 \\
\hline ZKB3-2 & $\begin{array}{l}\text { Midspan } \\
\text { Deflection } \\
(\mathrm{mm})\end{array}$ & 6.696 & 6.096 & 6.986 & 6.796 & 6.356 & 6.796 & 6.776 & 6.776 & 6.346 \\
\hline ZKB3-3 & $\begin{array}{c}\text { Bar } \\
\text { diameter } \\
(\mathrm{mm}) \\
\end{array}$ & 16 & 16 & 16 & 16 & 16 & 16 & 16 & 16 & 16 \\
\hline ZKB3-4 & $\begin{array}{c}\text { Yield } \\
\text { Strength, } \\
\text { fy (MPa) }\end{array}$ & 460 & 460 & 460 & 460 & 460 & 460 & 460 & 460 & 460 \\
\hline ZKBE-5 & $\begin{array}{l}\text { Ultimate } \\
\text { Tensile } \\
\text { Strength, } \\
\text { fu (MPa) }\end{array}$ & 629.9 & 630.8 & 630.4 & 630.4 & 630.4 & 630.4 & 630 & 630.5 & 630.5 \\
\hline ZKB3-6 & $\begin{array}{l}\text { Strain } \\
\text { Ratio } \\
\end{array}$ & 1.325 & 1.345 & 1.325 & 1.315 & 1.315 & 1.315 & 1.305 & 1.325 & 1.335 \\
\hline ZKB3-7 & $\begin{array}{l}\text { Elongation } \\
(\%)\end{array}$ & 26.65 & 27.27 & 26.75 & 26.72 & 27.17 & 26.95 & 26.86 & 26.57 & 27.23 \\
\hline
\end{tabular}

Table 4: Average Flexural Strength of Beam Specimens (Non-Corroded, Corroded Exudates/Resins Coated Specimens)

\begin{tabular}{|c|c|c|c|c|c|c|c|c|c|c|}
\hline \multirow{2}{*}{$\begin{array}{l}\text { s/no } \\
\text { ZKB4- } \\
1\end{array}$} & \multirow{2}{*}{$\begin{array}{l}\text { Samples } \\
\text { Failure } \\
\text { load (KN) }\end{array}$} & \multicolumn{3}{|c|}{$\begin{array}{l}\text { Non-Corroded Specimens } \\
\text { Average Values }\end{array}$} & \multicolumn{3}{|c|}{$\begin{array}{l}\text { Corroded Specimens Average } \\
\text { Values }\end{array}$} & \multicolumn{3}{|c|}{$\begin{array}{l}\text { Coated Specimens Average } \\
\text { Values }\end{array}$} \\
\hline & & 82.57 & 82.45667 & 82.92667 & 56.858333 & 55.805 & 55.885 & 82.401667 & 82.508333 & 82.47833 \\
\hline $\begin{array}{l}\text { ZKB4- } \\
2\end{array}$ & $\begin{array}{l}\text { Midspan } \\
\text { Deflection } \\
(\mathrm{mm})\end{array}$ & 6.773333 & 7.016667 & 6.476667 & 12.233333 & 11.933333 & 11.88667 & 6.5926667 & 6.6493333 & 6.632667 \\
\hline $\begin{array}{l}\text { ZKB4- } \\
3\end{array}$ & $\begin{array}{l}\text { Bar } \\
\text { diameter } \\
(\mathrm{mm})\end{array}$ & 16 & 16 & 16 & 16 & 16 & 16 & 16 & 16 & 16 \\
\hline $\begin{array}{l}\text { ZKB4- } \\
4\end{array}$ & $\begin{array}{l}\text { Yield } \\
\text { Strength, } \\
\text { fy (MPa) }\end{array}$ & 460 & 460 & 460 & 460 & 460 & 460 & 460 & 460 & 460 \\
\hline $\begin{array}{l}\text { ZKB4- } \\
5\end{array}$ & $\begin{array}{l}\text { Utimate } \\
\text { Tensile } \\
\text { Strength, } \\
\text { fu (MPa) }\end{array}$ & 628.9833 & 628.7167 & 628.4167 & 565.28333 & 563.75 & 563.8833 & 630.3667 & 630.4 & 630.3333 \\
\hline $\begin{array}{l}\text { ZKB4- } \\
6\end{array}$ & $\begin{array}{l}\text { Strain } \\
\text { Ratio }\end{array}$ & 1.317667 & 1.321 & 1.311 & 1.1735333 & 1.1802 & 1.163533 & 1.331667 & 1.315 & 1.321667 \\
\hline $\begin{array}{l}\text { ZKB4- } \\
7\end{array}$ & $\begin{array}{l}\text { Elongation } \\
(\%)\end{array}$ & 27.245 & 26.96833 & 27.36833 & 15.894333 & 15.674333 & 15.85433 & 26.89 & 26.94667 & 26.88667 \\
\hline
\end{tabular}


DOI : https://dx.doi.org/10.26808/rs.aj.i8v1.06

American Journal of Sustainable Cities and Society

Available online on http://www.rspublication.com/ajscs/ajsas.html

Issue 8, Vol. 1 January- December 2019 ISSN $2319-7277$

Table 5: Summary of Percentile Flexural Strength of Beam Specimens (Non-Corroded, Corroded, Exudates/Resins Coated Specimens)

\begin{tabular}{|c|c|c|c|c|c|c|c|c|c|c|}
\hline Beam & Samples & \multicolumn{3}{|c|}{ Summary of Averages } & \multicolumn{3}{|c|}{ Percentile Values } & \multicolumn{3}{|c|}{ Percentile variations } \\
\hline ZKB5-1 & $\begin{array}{c}\text { Failure } \\
\text { load }(\mathrm{KN})\end{array}$ & 82.65111 & 56.18278 & 82.46278 & 147.1111 & 67.97583 & 146.7759 & 47.11112 & -32.0242 & 46.7759 \\
\hline ZKB5-2 & $\begin{array}{l}\text { Midspan } \\
\text { Deflection } \\
(\mathrm{mm})\end{array}$ & 6.755556 & 12.01778 & 6.624889 & 56.21302 & 177.8947 & 55.12574 & -43.787 & 77.89474 & -44.8743 \\
\hline ZKB5-3 & $\begin{array}{c}\text { Bar } \\
\text { diameter } \\
(\mathrm{mm})\end{array}$ & 16 & 16 & 16 & 100 & 100 & 100 & 0 & 0 & 0 \\
\hline ZKB5-4 & $\begin{array}{c}\text { Yield } \\
\text { Strength, } \\
\text { fy }(\mathrm{MPa})\end{array}$ & 460 & 460 & 460 & 100 & 100 & 100 & 0 & 0 & 0 \\
\hline ZKB5-5 & $\begin{array}{l}\text { Ultimate } \\
\text { Tensile } \\
\text { Strength, } \\
\text { fu (MPa) }\end{array}$ & 628.7056 & 564.3056 & 630.3667 & 111.4123 & 89.75673 & 111.7066 & 11.41226 & -10.2433 & 11.70662 \\
\hline ZKB5-7 & $\begin{array}{l}\text { Elongation } \\
(\%)\end{array}$ & 27.19389 & 15.80767 & 26.90778 & 172.0297 & 58.12948 & 170.2198 & 72.02975 & -41.8705 & 70.21979 \\
\hline
\end{tabular}

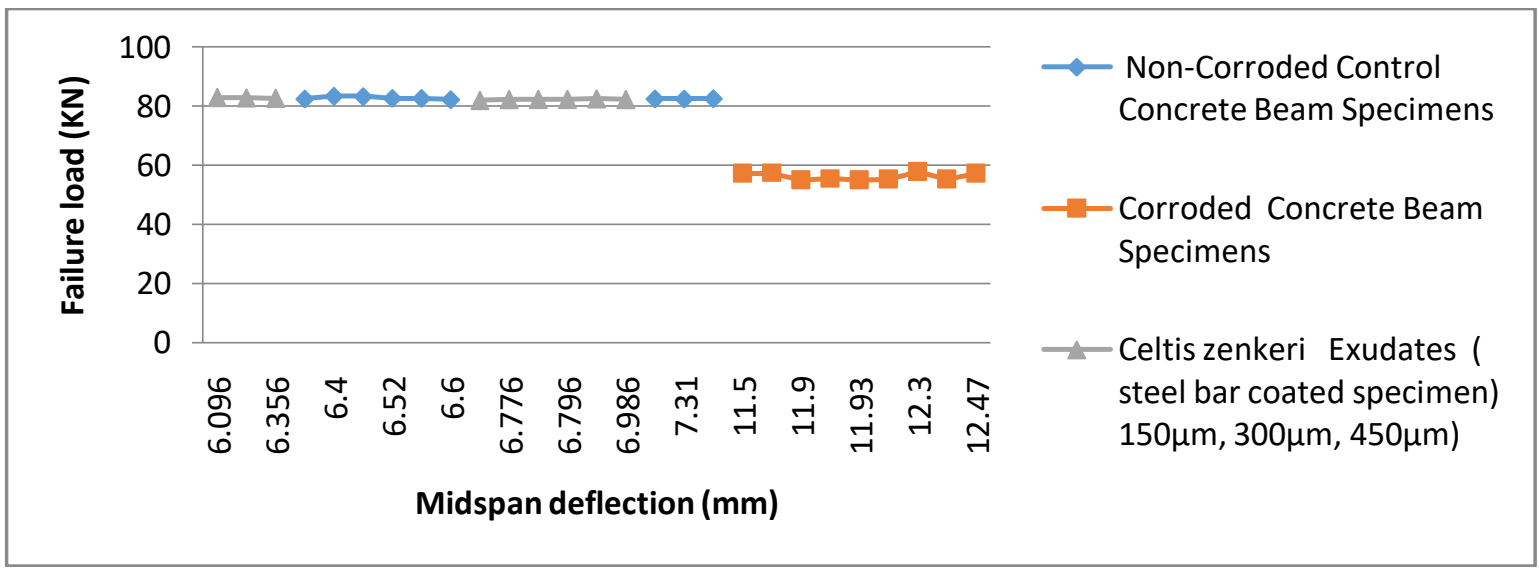

Fig. 1 Failure Load versus Midspan Deflection of Beam Specimens (Non-Corroded, Corrode and Resin Coated Specimens)

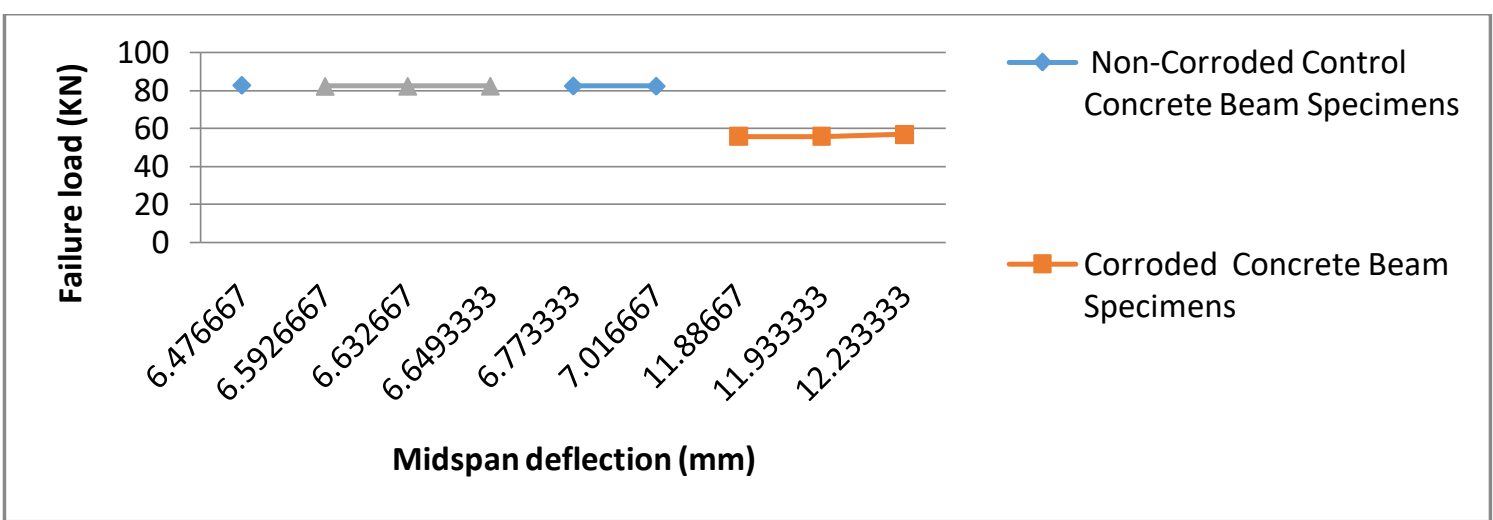

Fig. 2 Average Failure Load versus Midspan Deflection of Beam Specimens (Non-Corroded, Corrode and Resin Coated Specimens) 


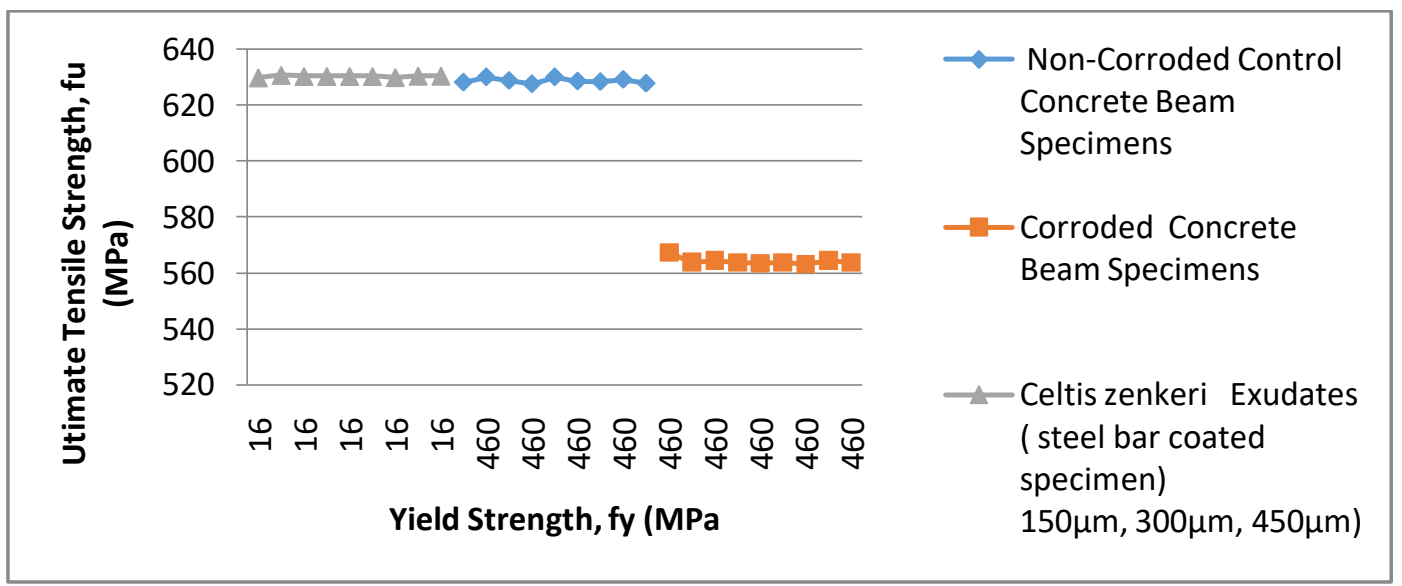

Fig. 3 Ultimate Tensile Strength versus Yield Strength of Beam Specimens (Non-Corroded, Corrode and Resin Coated Specimens)

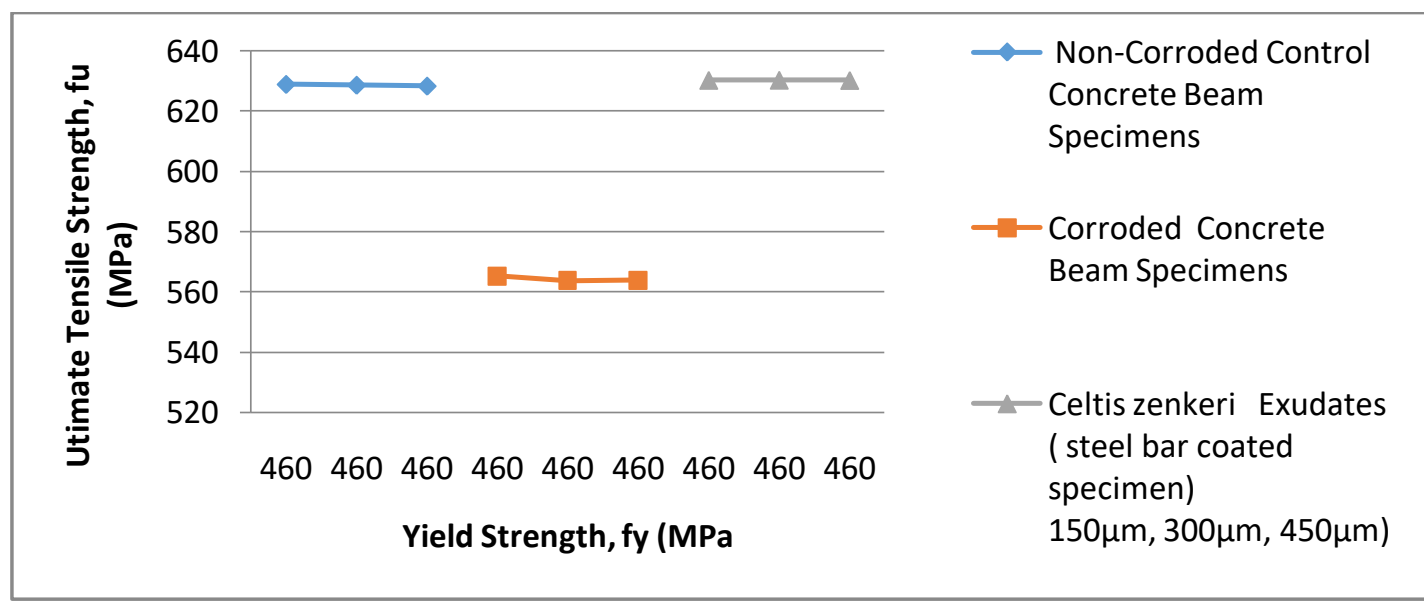

Fig. 4 Average Ultimate Tensile Strength versus Yield Strength of Beam Specimens (Non-Corroded, Corrode and Resin Coated Specimens)

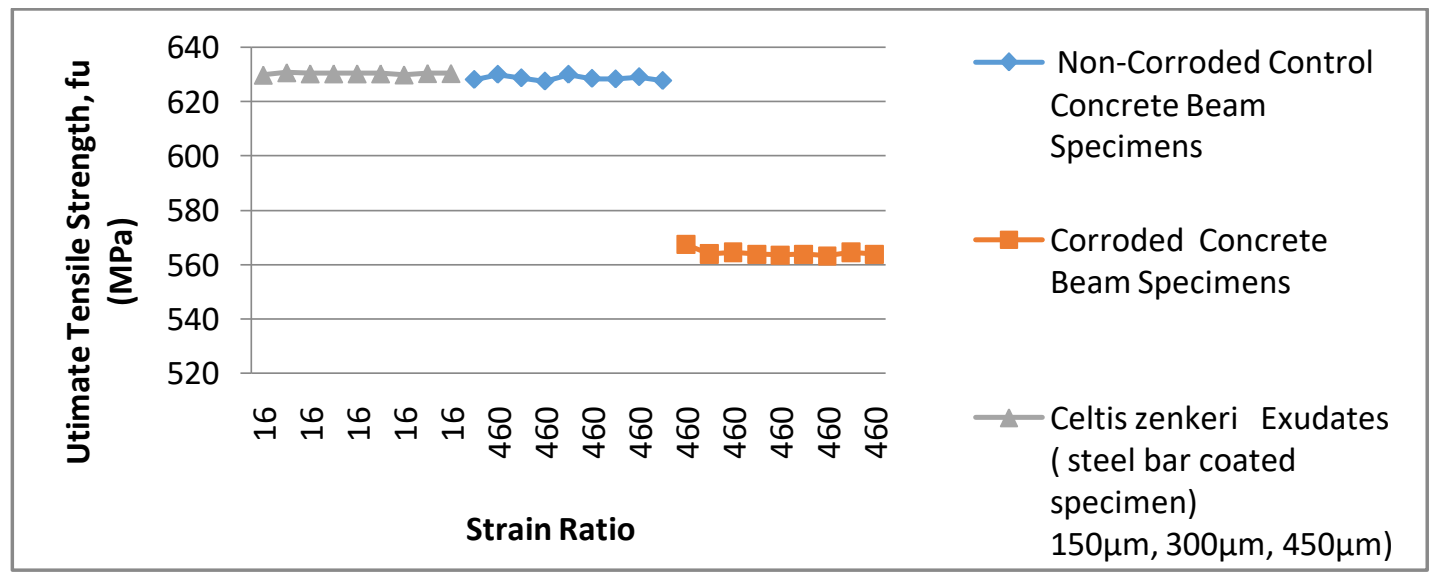

Fig. 5 Ultimate Tensile Strength versus Strain Ratio of Beam Specimens (Non-Corroded, Corrode and Resin Coated Specimens) 


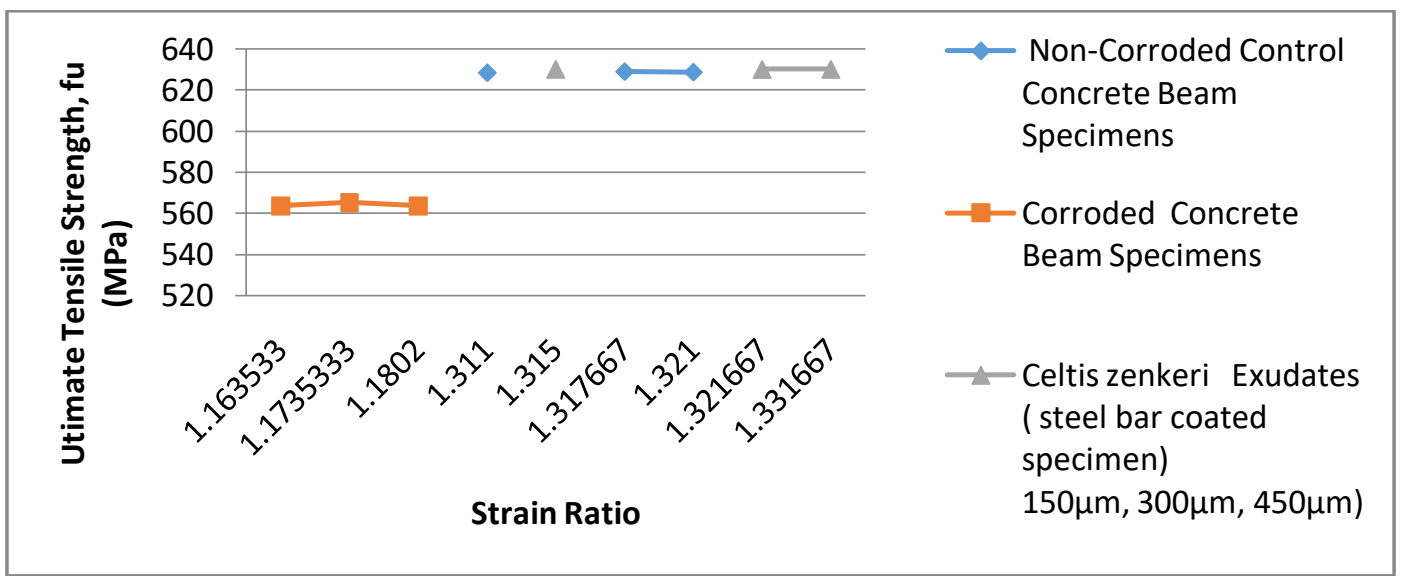

Fig. 6 Average Ultimate Tensile Strength versus Strain Ratio of Beam Specimens (Non-Corroded, Corrode and Resin Coated Specimens)

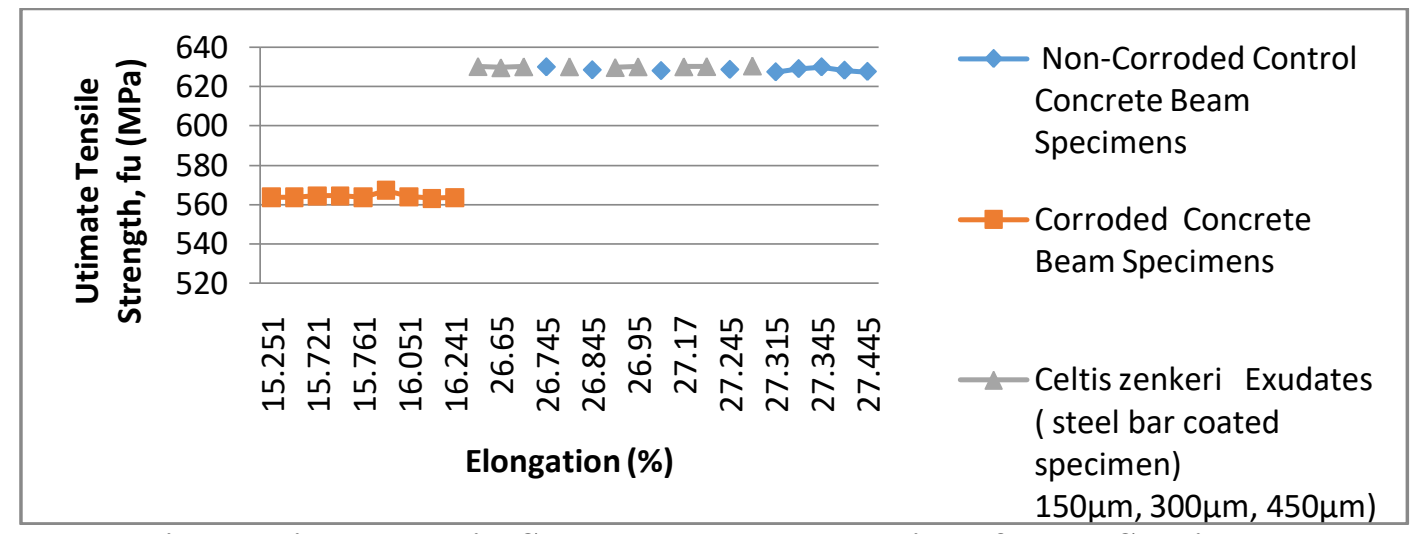

Fig. 7 Ultimate Tensile Strength versus Elongation of Beam Specimens (Non-Corroded, Corrode and Resin Coated Specimens)

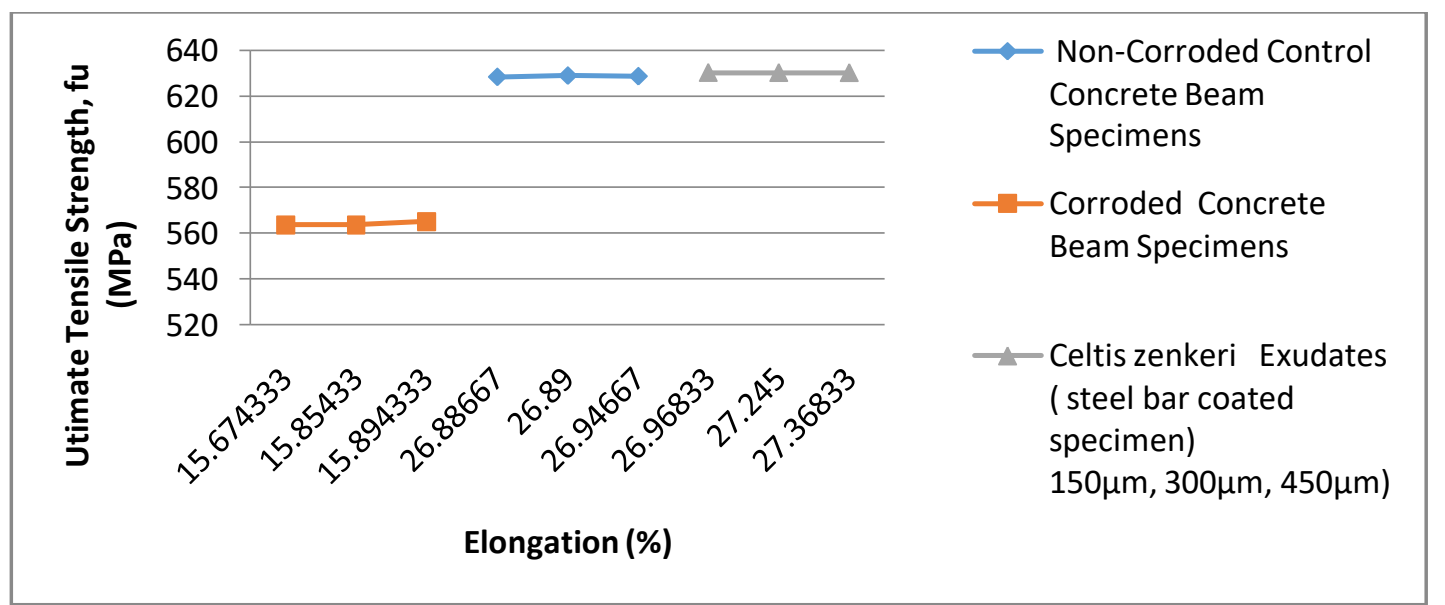

Fig. 8 Average Ultimate Tensile Strength versus Elongation of Beam Specimens (Non-Corroded, Corrode and Resin Coated Specimens)

\section{CONCLUSIONS}


Experimental results gotten from tables $1-5$ and figures $1-3$, the below conclusions were drawn:

i. Results of non-corroded members at flexural failure load, midspan deflection, yield strength, elongation and strain ratio, all maintained standard and state because they are cure within non-corrosive media.

ii. Comparative results of non- coated (corroded) to non-coated and coated members showed that corroded members have high flexural failure load with low applied load and high yields, low load with high midspan deflection.

iii. Experimental work showed that mechanical properties of reinforcing steel were adversely affected by corrosion with changed in surface properties of non-coated members, while coated members formed resistance surface to corrosion penetration and maintained standard structural properties of reinforcing steel

iv. Collated coated members result of exudates / resins showed lowers characteristic properties of flexural failure load, midspan deflection, strain ratio and ultimate tensile strength over non-coated (corroded) members in comparison.

\section{REFERENCES}

I. BS 882; 1992. - Specification for aggregates from natural sources for concrete, British Standards Institute. London, United Kingdom,

II. BS EN 196-6; 2010. - Methods of testing cement determination of fineness, British Standards Institute. London, United Kingdom.

III. BS 12390-5; 2005. - Testing Hardened Concrete: flexural strength test of specimens, British Standards Institute. London, United Kingdom.

IV. BS 12390-5; 2005. - Testing Hardened Concrete: Flexural strength test of specimens, British Standards Institute. London, United Kingdom.

V. Charles, K., Ishmael, O., Akatah, B. M., \& Akpan, P. P. 2018. Comparative residual yield strength structural capacity of non-corroded, corroded and inhibited reinforcement embedded in reinforced concrete structure and exposed to severely medium. International Journal of Scientific and Engineering Research, (9) 4: 11351149.

VI. Charles, K., Terence, T. T. W., Kelechi, O., \& Okabi, I. S. 2018. Investigation on comparative flexural residual yield strength capacity of uncoated and coated reinforcement embedded in concrete and exposed to corrosive medium. International Journal of Scientific \& Engineering Research, (9) 4: 655-670.

VII. Charles, K., Gbinu, S. K., \& Ugo, K. 2018. Load carrying capacity of coated reinforcement with exudates of concrete beam in corrosion solution ponding. International Journal of Civil and Structural Engineering Research, (6) 1: 5-12.

VIII. Charles, K., Ogunjiofor, E. I., \& Latam, L. P. 2018. Yield strength capacity of corrosion inhibited (resins / exudates) coated reinforcement embedded in reinforced concrete beam and accelerated in corrosive medium. European International Journal of Science and Technology, (7) 3: 25-33.

IX. Charles, K., Akpan, P. P., \& Gbinu, S. K. 2018. Corrosion effects on residual structural capacity of resins / exudates inhibited steel reinforcement flexural beam. European Journal of Engineering Research and Science, (3) 5: 31-35.

X. Charles, K., Ogunjiofor, E. I., \& Letam, L, P. 2018. Residual flexural strength of corrosion inhibited resin coated beam in corrosion accelerated media. Global Scientific Journal, (6) 5: 84-96.

I. Charles, K., Letam, L. P., \& Gbinu, S. K. 2018. Effect of Resins / Exudates Inhibited Steel on the Flexural strength of Reinforced Concrete Beam under Corrosive 
Environment. International Journal of Advances in Scientific Research and Engineering, (4) 4: 52-61.

II. Ell-Maaddawy, T. E., Soudki, K. \& Topper, T. 2006 -Analytical Model to Predict Nonlinear Flexural Behavior of Corroded Reinforced Concrete Beams. ACI Structural Journal, 102 (4): 550-559.

III. Huang, R., \& Yang, C. C. 1997. Condition Assessment of Reinforced Concrete Beams Relative to Reinforcement Corrosion. Cement and Concrete Composites, 19: 131-137.

IV. Otunyo A. W., \& Charles, K. 2018. Effect of corrosion on flexural residual strength and mid-span defelection of steel (coated with resins/exudates of trees) reinforced concrete beams under sodium chloride medium. European International Journal of Science and Technology, (6) 7: 77-87.

V. Rodriguez, J., Ortega, L. M., \& Casal, J. 1997. Load Carrying capacity of concrete structures with corroded reinforcement. Construction and Building Materials, 11 (4): 239-247.

VI. Ting, S. C., \& Nowak, A. S. 1991. Effect of reinforcing steel area loss on flexural behavior of reinforced concrete beams. ACI Structural Journal, 4: 309-314.

VII. Torres-Acost, A. A., Navarro-Gutierrez, S. \& Terán-Guillén, J. 2007. Residual flexure capacity of corroded reinforced concrete beams. Engineering Structures, 29 (6): 11421152. 